Winter 2010

\title{
Introduction: Eastphalia Emerging?: Asia, International Law, and Global Governance
}

\author{
David Fidler \\ Indiana University Maurer School of Law, dfidler@indiana.edu
}

Follow this and additional works at: https://www.repository.law.indiana.edu/ijgls

Part of the International Law Commons, and the Law and Politics Commons

\section{Recommended Citation}

Fidler, David (2010) "Introduction: Eastphalia Emerging?: Asia, International Law, and Global Governance," Indiana Journal of Global Legal Studies: Vol. 17 : Iss. 1 , Article 1.

Available at: https://www.repository.law.indiana.edu/ijgls/vol17/iss1/1

This Symposium is brought to you for free and open access by the Law School Journals at Digital Repository @ Maurer Law. It has been accepted for inclusion in Indiana Journal of Global Legal Studies by an authorized editor of Digital Repository @ Maurer Law. For more information, please contact rvaughan@indiana.edu.

\section{$\Psi$}

JEROME HALL LAW LIBRARY

INDIANA UNIVERSITY

Maurer School of Law
Blooming ton 


\title{
Introduction
}

\section{Eastphalia Emerging?: Asia, International Law, and Global Governance}

\author{
DAVID P. FIDLER ${ }^{*}$
}

\section{From Westrhalia to Eastphalia}

In the late eighteenth century, as part of his effort to stop British imperial despoliation of India, Edmund Burke argued that the people and civilization of India were moral equals of Europe, deserving of British respect rather than rapacious exploitation. "I assert," Burke argued, "that their morality is equal to ours as regards the morality of Governors, fathers, superiors; and I challenge the world to shew, in any modern European book, more true morality and wisdom than is to be found in the writings of Asiatic men in high trusts, and who have been Counsellors to Princes." Burke further argued that "in Asia as well as in Europe the same Law of Nations applies, the same principles continually resorted to, and the same maxims sacredly held and strenuously maintained" and that "Asia is enlightened in that respect as well as Europe." ${ }^{2}$ Burke's words fell on deaf ears; British imperialism in India proceeded apace. In the nineteenth century, other Asian cultures and states of ancient origin, especially China and Japan, found their traditional cultural and political practices determined by Western

* Faculty Editor for the Symposium; James Louis Calamaras Professor of Law, Indiana University Maurer School of Law-Bloomington; Director, Indiana University Center on American and Global Security. I would like to thank Hannah Buxbaum, Scott Kennedy, Ethan Michelson, and Virginia Ho for their advice and assistance in putting this symposium together.

1. Edmund Burke, Speech on Opening of Impeachment (Feb. 16, 1788), in 6 THE WRITINGS AND SPEECHES OF EDMUND BURKE-INDIA: THE LAUNCHING OF THE HASTINGS IMPEACHMENT, 1786-1788, 312, 361 (P. J. Marshall ed., 1991).

2. Id. at 367 .

Indiana Journal of Global Legal Studies Vol. 17 \#1 (Winter 2010)

(c) Indiana University Maurer School of Law 
imperial powers to be "uncivilized"3 and subject to dramatic changes at the hands of European nations and commercial interests. The twentieth century witnessed Asian countries emerge from colonialism into independent, sovereign states, but they often faced political and economic challenges in international affairs from a position of weakness. Not long ago, Asia's subjugation, exploitation, and vulnerability through its incorporation into the modern international system made the idea that Asian countries would one day reshape international politics from a position of strength a very distant dream.

The world may, however, be on the cusp of this possibility becoming reality. For a number of years, commentators on global affairs have been watching and analyzing the so-called "rise of Asia," a phenomenon largely driven by strong economic growth and development in India, China, East Asia, and Southeast Asia over the past twenty to thirty years. This perceived shift of material power and influence toward Asia provides Asian countries with their first real opportunity to significantly affect the structure and dynamics of international relations. This symposium attempts to provide insights into how this Asian opportunity might affect international law and global governance in twenty-firstcentury world politics.

Scholars of international politics and international law mark the beginnings of the modern international system with the Peace of Westphalia of 1648, which ended brutal wars Europeans had fought with each other for decades. The system of independent, sovereign states that developed after these wars ended came to be known as the "Westphalian" system. Asian countries and peoples were incorporated into this Westphalian system through European and Western imperialism in the eighteenth and nineteenth centuries. The world turned Westphalian as it became organized into territorial states possessing sovereignty and interacting through consent-based rules called the "law of nations" or, later, international law. The history of international law is largely a story written by Western countries, which extended the reach of this law to every corner of the earth and dominated the substantive nature of the rules and the institutions designed to support them.

After the end of the Cold War and the acceleration of the latest phase of globalization, experts began to speak of the world entering a "post-Westphalian" period. The end of the ideological conflict between the United States and the Soviet Union and the border-busting impact of globalization began to make central features of the Westphalian

3. See, e.g., GerRit W. GONG, The STANDARd OF 'Civilization' in INTERNATIONAL SOCIETY (1984). 
system, especially the principles of sovereignty and nonintervention in the domestic affairs of other states, look outdated and reactionary. In this post-Westphalian context, state and nonstate actors, predominantly from the West, began devising collective action mechanisms that went beyond traditional international law, leading many commentators to analyze the rise of "global governance."

This symposium poses the question whether the rise of Asia in global affairs might presage the emergence of an "Eastphalian" world order. The concept of "Eastphalia" attempts to capture the potential for Asian countries to reshape international politics, which have been long dominated by the influence, interests, and ideas of the West, in ways that reflect Asian power, principles, and practices more clearly. The possibility that an Eastphalian order might emerge under the impact of Asia's growing power and influence does not mean that Asian countries, especially China and India, will dominate the world through some form of Asian hegemony. Instead, the concept of Eastphalia is designed to focus attention on how the rise of Asia will affect international politics, international law, and global governance in the early twenty-first century. What will Asian-influenced world politics look like, and what roles will international law and global governance play in an Asiancentric world?

\section{SYMPOSIUM CONTRIBUTIONS}

To explore these questions, the Indiana Journal of Global Legal Studies invited scholars and experts from Asia and the United States to explore aspects of the potential impact of Asia's growing importance in international relations. The contributions represent a rich set of analyses that consider, among other things, conceptual implications for world affairs of Asia's rise to prominence; the importance of the behavior of the Asian great powers-China, India, and Japan; the impact of Asian power and ideas on the future of high-profile postWestphalian norms; and the response of key Asian states to challenges presented by globalized problems. However impressive, the articles in this symposium do not exhaust the questions raised by the prospect of Asian countries reshaping international relations, and the symposium's intent is to stimulate additional critical analysis and speculation about where Asia's ascendance might be taking world affairs.

We begin the symposium with two articles that explore conceptual and general implications of the rise of Asian countries in international relations. Professor Chang-fa Lo of National Taiwan University analyzes China's emergence as a great power and the ideas China 
promotes and practices in its foreign policy and international relations. ${ }^{4}$ Although China's development into a great power is commonly accepted, Professor Lo argues that the ideas preferred by Chinese leaders, particularly the Five Principles of Peaceful Coexistence (Five Principles), are neither distinctively Asian nor particularly helpful for states, international organizations, and nonstate actors trying to address transnational problems caused or exacerbated by globalization. Professor Lo argues that "[f]or Eastphalia to be something distinct, China must propose and practice ideas beyond the Five Principles that appeal to a wide spectrum of states and generate benefits for people in a globalized world."

Professor Tom Ginsburg of the University of Chicago Law School addresses similar themes in his contribution to the symposium. ${ }^{6}$ Professor Ginsburg centers his analysis about the impact of Asia's rise, and particularly the role of China in that rise, within larger conceptual debates about the direction world affairs may take. For example, he compares what may emerge in an Asian-dominated world with the governance trends seen within the European Union. For Professor Ginsburg, Asia's increasing importance represents a challenge to the globalization of Western-led universalism and European-led constitutionalism because Asian countries currently show little to no inclination to follow these directions in their relations with each other or the wider world. In light of this situation, he asks whether the leader of the Burmese political opposition, Aung San Suu Kyi, should be worried about the impact of a more powerful China and Asia on the rest of the world. According to Professor Ginsburg, how Asia, and particularly China, might influence international relations is not clear, and multiple possibilities exist, including the following one:

Even if East Asia emerges as the single dominant region of the world, a convergence in preferences may also occur such that Eastphalia reflects current European trends toward global constitutionalism. . . . This possibility would require an acceleration of integration in Asia itself and the adoption of a set of norms and preferences among peoples of the region that is compatible with the constitutionalist vision. It is a vision of convergence, in which Asian values become European

4. Chang-fa Lo, Values to Be Added to an "Eastphalian Order" by the Emerging China, 17 IND. J. GLOBAL LegaL STUd. 13 (2010).

5. Id. at 25 .

6. Tom Ginsburg, Eastphalia as the Perfection of Westphalia, 17 IND. J. GLOBAL LEGAL STUD. 27 (2010). 
values and vice versa. It is a vision that Aung San Suu Kyi could live with, as could many of us. ${ }^{7}$

The next symposium contribution comes from Professor Men Honghua, Deputy Director of the Center of International Strategic Studies of the Party School of CPC Central Committee in Beijing, China. Professor Men's article argues that a critical component of the future contributions Asia can make to world affairs is the strategic relationship between Japan and China. ${ }^{8}$ Professor Men applies the literature about regional order formation to the Sino-Japanese relationship, and he discusses the five key dynamics of the evolving order in East Asia: (1) regional economic integration and its spillover effects, (2) China's comprehensive and peaceful rise, (3) Japan's pursuit of greater political roles in the world and the region, (4) the leading role and normative influence of the Association of Southeast Asian Nations (ASEAN), and (5) the strategic adjustments being made by the United States. He analyzes imbalances in the region that might affect the future of urder in East Asia, and he proposes a "common interests-based framework" to help improve Sino-Japanese relations, regional order in East Asia, and the potential for Asia to play a more influential role in the world. He concludes: "For China and Japan, this vision is not only a great challenge, but it is also an unprecedented opportunity. Great nations must think before they act. It is high time for China and Japan to think more clearly about their interests and responsibilities nationally, regionally, and globally, and begin to act on strategic choices that will benefit their people, Asia, and the entire world."10

In contrast to Professor Men's detailed analysis of order in East Asia, Sung Won Kim's contribution examines how the rise of Asia, and China in particular, might affect the normative concept of "human security." 11 Kim, who works in the Ministry of Foreign Affairs and Trade of the Republic of Korea, reviews the ideas informing the human security norm, and he considers the prospects for Asia to become a region of potentially cutting-edge work on human security: "Asia today contains the best of the first world and the worst of the third world, which makes the region such a fascinating potential laboratory for

7. Id. at 45 .

8. Men Honghua, East Asian Order Formation and Sino-Japanese Relations, 17 IND. J. Global LeGal STUD. 47 (2010).

9. Id. at 75 .

10. Id. at 82 .

11. Sung Won Kim, Human Security with an Asian Face?, 17 IND. J. GLoBAL LegaL STUD. 83 (2010). 
global governance on human security." 12 This promise, however, is undercut by Asian countries' embrace of strong principles of sovereignty and nonintervention, which run counter to the thrust of the human security norm. Kim explores whether Confucianism might provide an Asian philosophical perspective to support Asian leadership on human security. In the end, though, Kim expresses concern about the impact of Asia's rise on the norm of human security, and he concludes that "the Asian approach to international relations and the prevailing postWestphalian nature of the human security concept do not share much, if any, common ground. In short, the Asian perspective offers little for advocates of human security to embrace."13

The next contribution comes from Professor Yanzhong Huang of Seton Hall University, who analyzes how global health has become part of China's foreign policy thinking. ${ }^{14}$ Professor Huang's article provides a detailed analysis of how China, a rising Asian great power, has addressed global health challenges in its foreign policy historically and in the contemporary era. His analysis is valuable because he explores in depth how China has adjusted its foreign policy thinking to address the increasingly globalized threat infectious diseases pose. In particular, Professor Huang demonstrates the significant impact China's mishandling of the severe acute respiratory syndrome (SARS) outbreak in 2003 had on its policy makers. After SARS, Professor Huang argues, China has exhibited a new approach to health as a foreign policy issue, including (1) being more transparent and cooperative, (2) showing greater interest in multilateralism in global health, (3) reinvigorating its health diplomacy in Africa, and (4) making Southeast Asia a new priority for its health diplomacy. This article is also valuable because it provides one of the few fine-grained analyses of how the relationship between health and foreign policy has developed in a major power in the international system. However, Professor Huang cautions against getting too excited about the new version of Chinese health diplomacy. He concludes that, "[a]lthough China recognizes that solutions to global health problems necessitate neoliberal strategies of cooperation over disease prevention and control, its actions on global health problems are still justified from the lens of classical realism that focuses on power, influence, and security." 15

\footnotetext{
12. Id. at 101 .

13. Id. at 102 .

14. Yanzhong Huang, Pursuing Health as Foreign Policy: The Case of China, 17 IND. J. Global LEGAL STUD. 105 (2010).

15. Id. at 145 .
} 
The final symposium contribution is written by Professors David P. Fidler and Sumit Ganguly of Indiana University, and focuses on India. ${ }^{16}$ We trace India's development into an emerging Asian great power and analyze how India's rise to geopolitical prominence might affect the nature of an Asian-centric international system. Like China and the member states of ASEAN, India embraces the Five Principles as normative concepts that guide its foreign policy and relations with other nations. The Five Principles have not, however, provided India with clear guidance as to how its leaders should shape and use India's growing power and influence. We argue that Indian policy makers exhibit indecisiveness at this key turning point in India's role in world politics. We also point out that at least two paths are possible for India in terms of the emergence of an Eastphalian order: India could become irrelevant or it could become indispensable in the unfolding process of Asia's impact on international relations. We conclude:

India's role in the possible coming of an Eastphalian order is enigmatic for many reasons, including the paradox of India's commitment to democracy internally and its dedication to strong principles of sovereignty and noninterference internationally. This situation creates confusion and potential conceptual obstacles for Indian development of distinctive contributions to the operation of legal rules and governance mechanisms in Eastphalia. ${ }^{17}$

\section{THEMES FROM THE SYMPOSIUM CONTRIBUTIONS}

The symposium contributions, collectively, raise a number of themes that illuminate how the rise of Asia might affect international law and global governance. These themes provide insights into what an Eastphalian international order might look like, how it might operate, and where it might have weaknesses. These insights remain, of course, speculative because, in international politics, reality often turns out different from prognostication, but the effort to peer, however dimly, into the future can produce some awareness of what might transpire.

16. David P. Fidler \& Sumit Ganguly, India and Eastphalia, 17 IND. J. GLOBAL LEGAL STUD. 147 (2010).

17. Id. at 163 . 


\section{A. Structural Influences on International Law and Global Governance: Asia's Rise and Multipolarity}

The symposium articles reflect a theme seen in other literature about the rise of Asia-the impact the emergence of China and India as great powers will have on the structure of the international system. The post-Westphalian international system began in earnest with the end of the Cold War and was dominated by Western countries, particularly the United States. The system was often described as "unipolar," "hegemonic," or "quasi-hegemonic" because of the predominance of U.S. power and influence. With China and India developing into great powers, the rise of Asia might make multipolarity the structural characteristic of the next phase of the international system's evolution. Multipolarity last characterized the structure of the international system in the nineteenth century and the first half of the twentieth century, but the great powers in these periods were, except for Japan, all Western countries. The new multipolarity that might arise through China's and India's emergence as great powers will mark the first time that Asian countries help determine key structural features of the international system.

The structure of the international system affects how states, international organizations, and nonstate actors utilize international law and global governance. Some of the structural impact relates to the scope and substance of international law and global governance mechanisms (see below), but structural change can also affect the environment in which such law and mechanisms operate. For example, multipolarity might make reaching effective collective action among states more difficult because it becomes harder to get multiple great powers to have converging interests and agree to common approaches. The U.S. National Intelligence Council has referred to this possible context as reflecting "multipolarity without multilateralism."18

This effect is a function of structure and does not reflect anything distinctively Asian, even though the structural change occurs because of the shift of material power and influence toward Asian countries. In short, the emergence of multipolarity through China's and India's development into great powers might make the political conditions in which states, international organizations, and nonstate actors use international law and global governance mechanisms more difficult, potentially limiting the amount of effective collective action against existing or newly emerging regional or global problems that can be

18. U.S. NAT'L INTELLIGENCE COUNCL, GLOBAL TRENDS 2025: A TRANSFORMED WORLD 81 (Nov. 2008), available at http://www.dni.gov/nic/PDF_2025/ 2025_Global_Trends_Final_Report.pdf. 
achieved.

As the multipolar international systems of the nineteenth century and the first half of the twentieth century suggest, structural multipolarity can create suspicion, distrust, and competition for influence among the great powers. Tensions between the great powers of the first decades of the twenty-first century might also arise, further limiting the potential for international cooperation on regional and global problems. Some potential difficulties resulting from the international system getting crowded with more rival powers can be glimpsed in the problems created by the changing relationship between China, as the emerging Asian power, and Japan, the traditional economic powerhouse of the region. Challenges created by a multipolar system might manifest themselves, for example, in the politics within the Group of Twenty (G-20), which replaced the Western-dominated Group of Eight (G-8) in 2009 as the leading global forum for economic policy.

\section{B. Scope and Substance of International Law and Global Governance: Whither the Five Principles?}

Another theme that emerges from the symposium contributions is the possibility that a multipolar system more heavily influenced by Asian countries might affect the scope and substance of international law and global governance. As many articles in the symposium note, Asian countries place significant value on the Five Principles in their relations with each other and with countries outside of the Asian region, such as in Africa. ${ }^{19}$ The Five Principles are more state-centric and conservative than the more universalistic and interventionist ideas and norms Western countries espoused after the end of the Cold War. Asian emphasis on sovereignty and nonintervention does not mean that Asian countries fail to participate in international legal regimes (e.g., trade agreements) and global governance mechanisms (e.g., the International Health Regulations 2005), so the rise in political importance of the Five Principles does not signal the end of the utility of international law and global governance. However, whether Asian commitment to the Five Principles might limit the scope and substance of international law and global governance in the new multipolar system is a relevant question.

Thinking about this question must reflect the probability that Asian use of the Five Principles in the future will likely not resemble Asian use of the principles during decolonization and the Cold War. In those

19. See Fidler \& Ganguly, supra note 16, at 156; Ginsburg, supra note 6, at 32; Kim, supra note 11, at 95; Lo, supra note 4, at 15 . 
earlier times, the Five Principles were deployed mainly in a defensive manner by Asian countries that were weak politically and economically and vulnerable to outside pressure and interference from stronger states. Although concerns about outside intervention have not disappeared, as evidenced by China and India continuing to bristle over human rights criticisms, the stronger Asian countries, such as those members of the G-20 (China, India, Indonesia, Japan, and South Korea), no longer equate, for example, economic interdependence with threats of foreign intervention.

Asian countries and societies have become more globalized through their choices to integrate into global markets for goods, services, technologies, and investment capital. The most dramatic examples of change in this regard are, of course, China and India, both of which for decades after the Second World War avoided interconnections with other countries in favor of autarkic political and economic development. Now China's and India's emerging power and influence come from following policies that reject autarky in favor of deeper levels of political cooperation and economic interdependence. In addition, Asian countries also realize their vulnerability to many global problems, such as the spread of infectious diseases, global financial crises, and the dangers of climate change, which require serious levels of international cooperation. The globalization of Asian policy making now makes Asian countries less wary about collective action from the perspective of the Five Principles than once they were.

Nevertheless, the legacy of Asian commitment to the Five Principles, combined with the frequency with which Asian countries continue to appeal to these principles, means that these norms will constitute more than empty rhetoric in an international system more heavily influenced by Asia. As noted in a number of the symposium articles, the continued importance of the Five Principles creates difficulties for human rights, the concept of human security, democracy promotion, and the idea of humanitarian intervention, including in its latest manifestation as the principle of the responsibility to protect. Both India and China highlight the Five Principles in their increasing activities in Africa, and ASEAN members continue to emphasize these principles (e.g., with respect to Myanmar), even as they have moved tentatively toward a regional human rights process. Weaker countries in Asia still embrace the Five Principles as potential ammunition against any temptations stronger Asian powers, especially China and India, might have to throw their political weight around.

Thus, one of the most important and interesting things to watch as power and influence continue to shift toward Asia is how Asian countries adapt their commitment to the Five Principles to the 
opportunities and challenges a multipolar, Asian-influenced, and globalizing international system will create. The nature of this adaptation will affect how countries utilize international law and global governance mechanisms in an Eastphalian system and what substantive innovations in such law and mechanisms, if any, will arise in the future.

\section{Sustainability of Eastphalia: Rise and Fall of Asian Influence and Ideas?}

A final theme worth mentioning asks whether the rise of Asian power and influence will be sustained and generate more permanent changes in the nature of international relations. European great powers had such an impact during their heyday in the nineteenth century and the first half of the twentieth century, and the United States did likewise during its superpower and quasi-hegemonic moments in the twentieth and early twenty-first centuries. Whether Asian countries can sustain their current rise to prominence over time and in ways that reshape world affairs remains to be seen, but many questions exist about the probability of this outcome.

Asian rivalries might deepen and increasingly pit Asian countries against each other, draining notions of Asian solidarity of any import. In addition, as Kim argues in his article, Asia experiences the best of the first world and the worst of the third world across its immense geographical extent. The gap between these two worlds might expand within Asia and within Asian countries, undermining their ability to maintain the political, economic, and social growth and stability that has made the world turn its eyes toward Asia. Similarly, China and India face enormous domestic problems that might sap their means and willingness to shoulder the responsibilities and burdens of being a great power in an Asian-centric international system. Or, as Ginsburg posits, Asian countries may find their interests and ideas converging with those developed by the West, such that Asia again becomes a follower and adapter of Western ways rather than being a source of a distinctive approach to international relations, international law, and global governance.

\section{CONCLUSION}

The articles in this symposium provide much food for thought with respect to the potential impact of the rise of Asia on the structure of the international system, the scope and substance of international law and global governance, and the sustainability of Asian influence, interests, 
and ideas in world affairs. The possibility of the emergence of an Eastphalian international system remains just that-a possibility. But, it is a possibility permeated with potentially historic implications as Asian countries are, for the first time since the modern international system emerged in Europe in the seventeenth century and went global in the eighteenth and nineteenth centuries, poised to shape international relations according to their interests, influence, and ideas. Asia stands on the threshold of an opportunity that aims not for the recognition of Asia's moral equivalence and enlightenment that Edmund Burke tried to emphasize in a bygone age, but rather for Asian countries to show leadership in how the governance of human affairs will unfold in the coming decades. What Asian countries make of this unprecedented confluence of events may well be one of the most important tales to emerge from the triumphs and travails of the twentyfirst century. 